\title{
Keterampilan Geometri Siswa Kelas IV Sekolah Dasar Berdasarkan Teori Van Hiele Level Analisis
}

\author{
Widi Candika Pakaya ${ }^{1}$, Abdul Qohar ${ }^{2}$, Susiswo $^{2}$ \\ ${ }^{1}$ Pendidikan Dasar-Universitas Negeri Malang \\ ${ }^{2}$ Pendidikan Matematika-Universitas Negeri Malang
}

\begin{tabular}{l}
\hline \hline INFO ARTIKEL \\
\hline Riwayat Artikel: \\
Diterima: 04-03-2019 \\
Disetujui: 13-03-2019 \\
\hline
\end{tabular}

\section{Kata kunci:}

geometry skills; van hiele theory; fourth grade students; keterampilan geometri; teori van hiele; siswa kelas IV

\begin{abstract}
ABSTRAK
Abstract: This research was aimed to describe the geometry skills of students at Van Hiele's level of analysis. This study uses descriptive qualitative methods. Data is collected through interviews, recording, and student work. The research subjects amounted to 2 students, namely those who reached the level of analysis according to Van Hiele's theory in the 4th grade. The results of this study were students who reached the level of analysis according to Van Hiele's theory were able to do the questions well on visual, verbal, drawing, and applied skills even though they could not be fully completed. As for logic skills, the analysis level students are unable to answer the question correctly.
\end{abstract}

\begin{abstract}
Abstrak: Penelitian ini bertujuan untuk mendeskripsikan keterampilan geometri siswa level analisis Van Hiele. Penelitian ini menggunakan metode deskriptif kualitatif. Data dikumpulkan melalui wawancara, perekaman, dan pekerjaan siswa. Subjek penelitian berjumlah dua orang siswa yaitu siswa yang mencapai level analisis menurut teori Van Hiele di kelas IV. Hasil penelitian ini adalah siswa yang mencapai level analisis menurut teori Van Hiele mampu mengerjakan soal dengan baik pada keterampilan visual, verbal, menggambar, dan terapan meskipun belum sepenuhnya dapat diselesaikan. Untuk keterampilan logika, siswa level analisis tidak mampu menjawab soal tersebut dengan benar.
\end{abstract}

\author{
Alamat Korespondensi: \\ Widi Candika Pakaya \\ Pendidikan Dasar \\ Universitas Negeri Malang \\ Jalan Semarang 5 Malang \\ E-mail: widicandikapakaya@gmail.com
}

Geometri merupakan ilmu yang menghubungkan matematika dengan kehidupan nyata. Banyak benda dalam kehidupan seharihari yang memiliki bentuk yang sama dengan bangun geometri, misalnya lemari, buku, kotak pensil, kotak kado dan lain-lain. Menurut $\mathrm{Wu} \& \mathrm{Ma}$ (2010), geometri merupakan salah satu materi yang paling penting dalam matematika. Geometri juga merupanan keterampilan dasar yang perlu dipelajari oleh siswa (NCTM, 2000). Menurut Rafianti (2016), siswa memerlukan suatu pemahaman konsep yang baik dalam mempelajari geometri sehingga siswa mampu menggunakan keterampilan geometri yang dimiliki seperti memvisualisasikan, mengenal bangun-bangun geometri, memaparkan definisi bangun, mengonstruksi bangun dan mengungkapkan persamaan serta perbedaan antara bangun-bangun geometri. Selanjutnya, untuk menyelesaikan masalah geometri membutuhkan pola pikir dengan menerapkan keterampilan dan juga konsep dalam menyelesaikan masalah tersebut. Namun kenyataanya, kesulitan dalam mempelajari dan menyelesaikan soal-soal geometri masih banyak dialami oleh siswa.

Hasil penelitian yang dilakukan oleh Ningrum, Yulianti, Helingo \& Budiarto (2017) diperoleh fakta bahwa siswa mengalami kesalahpahaman dengan konsep sifat persegipanjang. Kesalahpahaman siswa terjadi karena siswa tidak mengenali gambar yang diberikan. Mereka menganggap bahwa persegi panjang selalu dalam posisi yang sama dan memiliki bentuk yang sama seperti persegi panjang lainnya, sedangkan penelitian yang dilakukan oleh Ozkan \& Bal (2017) menyatakan bahwa siswa mengalami kesalahpahaman dengan konsep persegi. Siswa menganggap persegi itu sebagai setengah persegi panjang.

Berdasarkan hasil penelitian di atas, secara umum siswa belum memahami sifat-sifat dari bangun datar. Pemahaman siswa tentang sifat-sifat bangun datar merupakan salah satu keterampilan geometri. Menurut Rahimah \& Asy'ari (2017), keberhasilan siswa dalam menyelesaikan masalah geometri dipengaruhi oleh keterampilan geometri. Keterampilan geometri teridiri dari lima keterampilan yang dikemukakan oleh Hoffer (2008), meliputi keterampilan visual, keterampilan verbal, keterampilan menggambar, keterampilan logika, dan keterampilan terapan. 
Menurut Heruman (2007), secara bertahap pembelajaran geometri diajarkan sesuai jenjang tingkat kelas. Jenjang kelas I Sekolah Dasar, siswa mempelajari tentang mengenal bangun datar dan bangun ruang melalui pembelajaran visualisasi dan benda-benda nyata yang diperagakan. Kelas II Sekolah Dasar, siswa mengidentifikasi unsur-unsur pembentuk bangun segitiga dan segiempat, memilah dan mengelompokkan bangun berdasarkan sifat geometrisnya. Kelas III Sekolah Dasar, siswa memahami dan menemukan sifat-sifat bangun datar sederhana berdasarkan pengamatan, memahami keliling dan luas persegi panjang, mendeskripsikan hubungan antar bangun. Kelas IV Sekolah Dasar, siswa memahami luas persegi, segitiga, persegipanjang, dan menyelesaikan masalah yang berkaitan dengan luas dan keliling persegi, segitiga, dan persegipanjang.

Berdasarkan penjelasan di atas dapat diketahui bahwa siswa kelas IV Sekolah Dasar sudah mempelajari bangun datar sesuai dengan keterampilan geometri yang terdiri dari (1) keterampilan visual, meliputi kemampuan untuk mengidentifikasi bentuk geometri berdasarkan pengamatan yang dapat dilihat secara langsung; (2) keterampilan verbal, meliputi kemampuan untuk mendefinisikan suatu bangun berdasarkan karakteristik atau sifat yang ada pada bangun; (3) keterampilan menggambar, meliputi kemampuan untuk mengonstruksi suatu bangun berdasarkan sifat dan karakteristik yang dimilikinya; (4) keterampilan logika, meliputi kemampuan untuk memahami keterkaitan antar bangun; (5) keterampilan terapan, meliputi kemampuan untuk menghubungkan konsep geometri dan mengembangkan model yang diberikan untuk memecahkan masalah.

Selain keterampilan geometri, siswa juga membutuhkan perlakuan yang berbeda dari guru. Perlakuan yang diberikan oleh guru (pendekatan pembelajaran, strategi, model, maupun metode yang digunakan guru) cenderung sama untuk setiap siswa, sedangkan, setiap siswa memiliki cara berpikir dan belajar yang berbeda-beda. Musser, Burger \& Peterson (2011) menyebutkan bahwa proses pembelajaran geometri di tingkat dasar dan menengah tidak terlepas dari teori Van Hiele. Van Hiele merupakan seorang guru matematika yang menulis disertasi mengenai pengajaran geometri pada tahun 1954. Disertasinya tersebut ditulis berdasarkan dari hasil penelitiannya di lapangan melalui tanya jawab dan observasi. Ia mendapatkan kesimpulan bahwa terdapat lima level pemahaman tentang geometri dengan setiap level merupakan prasyarat untuk naik ke level berpikir yang lebih tinggi. Level siswa dalam memahami dan mempelajari geometri itu adalah level 0 (visualisasi), level 1 (analisis), level 2 (deduksi informal), level 3 (deduksi), dan level 4 (rigor) (Wu \& Ma, 2006; Burger \& Shaughnessy, 2016; Škrbec \& Čadež, 2015).

Level berpikir tertinggi siswa kelas IV SD dalam mempelajari geometri menurut teori Van Hiele telah sampai pada level 1 yaitu tahap berpikir analisis. Hal ini didasarkan dengan pendapat Kim (2016) yang mengungkapkan bahwa sebagian besar siswa kelas IV SD mencapai level 0 sampai level 1. Siswa yang mencapai level 1 Van Hiele telah melalui level 0, sehingga siswa yang mencapai level 1 Van Hiele juga memiliki pengetahuan yang terdapat di level 0. Jadi, dapat dikatakan bahwa apabila siswa berada pada level 1 dalam level perkembangan berpikir Van Hiele, maka siswa tersebut juga memiliki kemampuan pada level 0 yaitu mampu mengenal bangun geometri berdasarkan bentuk dan penampakkannya (Vojkuvkova, 2012). Berdasarkan uraian di atas, penulis ingin mengetahui keterampilan geometri siswa pada level pemikiran geometri tertinggi di kelas IV SD yaitu level 1 (analisis). Oleh karena itu, peneliti menentukan judul penelitian "Keterampilan Geometri Siswa Kelas IV SD Berdasarkan Teori Van Hiele Level Analisis"

\section{METODE}

Tempat yang dipilih untuk penelitian adalah SD Islam Mohamad Hatta. Penelitian ini menggunakan metode kualitatif deskriptif. Pemilihan subjek penelitian dilakukan dengan menggunakan teknik purposive sampling. Pemilihan subjek harus mempertimbangkan level berpikir Van Hiele. Setelah siswa dikategorikan dalam level berpikir Van Hiele, kemudian diambil dua siswa yang mencapai level 1 (analisis) Van Hiele. Siswa yang lancar dalam berkomunikasi merupakan salah satu hal yang harus dipertimnbangkan dalam menentukan subjek penelitian. Jadi, penentuan dua subjek dilihat dari hasil tes Van Hiele dan saran dari guru kelas yang memahami kemampuan siswa dalam berkomunikasi.

Teknik pengumpulan data yang digunakan berupa tes tulis dan wawancara. Tes yang digunakan dalam penelitian ini adalah tes VHGT dan tes keterampilan geometri. Tes VHGT digunakan untuk menentukan level berpikir geometri siswa yang dikembangkan oleh Usiskin. Peneliti menerjemahkan tes VHGT ke dalam bahasa Indonesia sehingga mudah untuk digunakan. Sebelum tes VHGT digunakan, instrumen tes tersebut divalidasi terlebih dahulu. Berdasarkan hasil tes VHGT dan saran dari guru kelas, maka dipilih dua subjek yang telah mencapai level 1 (analisis) Van Hiele, yaitu subjek CAJ dan ADS. Selanjutnya, peneliti memberikan tes keterampilan geometri dan melakukan wawancara. Setelah subjek melaksanakan tes keterampilan geometri, subjek diwawancara untuk memperoleh informasi lebih dalam mengenai keterampilan geometri siswa level 1 (analisis) Van Hiele. Aktivitas dalam analisis data dibagi menjadi tiga tahapan, yaitu reduksi data, penyajian data, dan penarikan kesimpulan (Sugiyono, 2015). Berikut merupakan tes keterampilan geometri, sebagaimana ditunjukkan pada tabel 1. 
Tabel 1. Tes Keterampilan Geometri

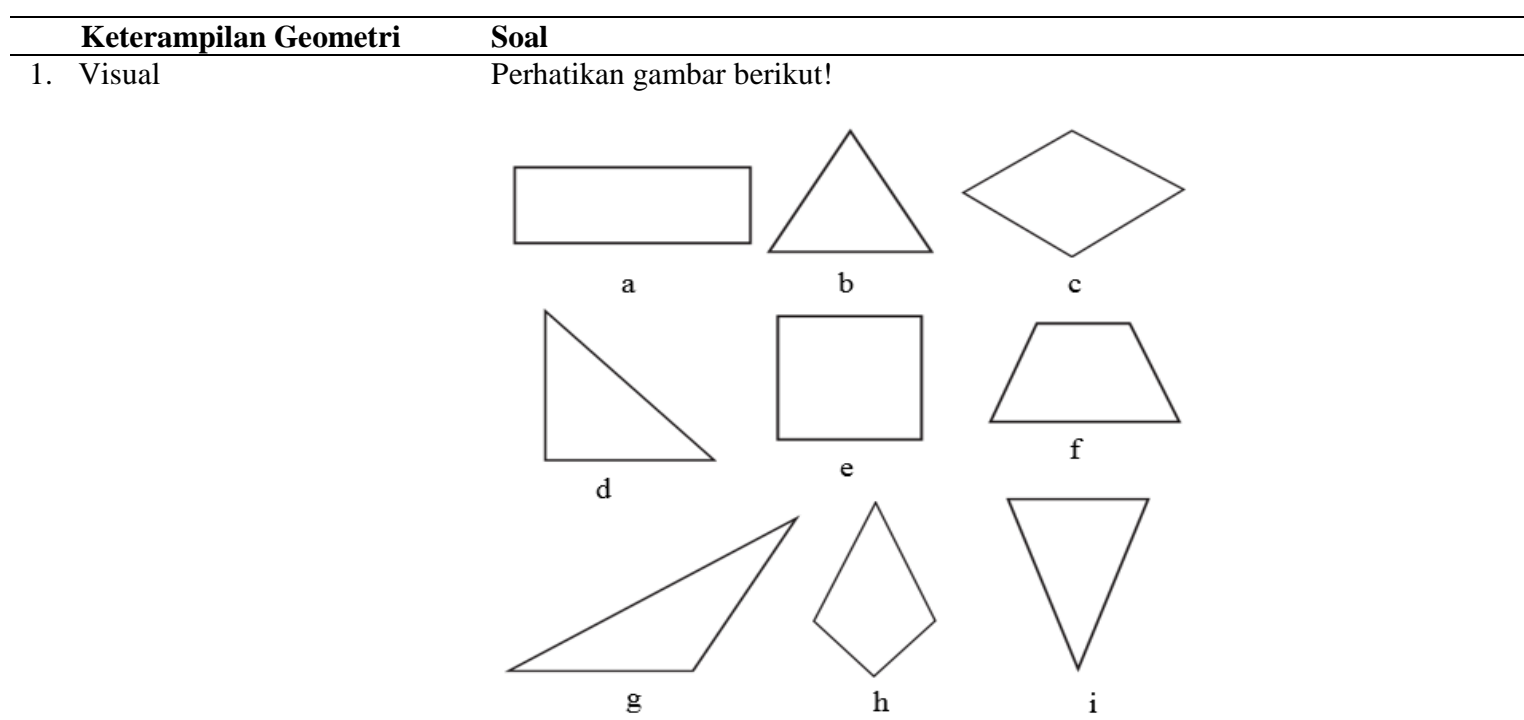

2. Verbal

Kelompokkan bangun di atas ke dalam kelompok-kelompok bangun segiempat dan segitiga serta berikan alasan!

Perhatikan gambar berikut!

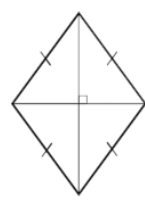

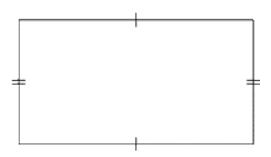

3. Menggambar

4. Logika

5. Terapan

Sebutkan nama bangun di atas dan tuliskan sifat-sifat dari bangun tersebut!

Berikut ini merupakan sifat-sifat dari sebuah bangun:

- Masing-masing sepasang sisi yang berdekatan sama panjang

- Tepat satu pasang sudut yang berhadapan sama besar

- Salah satu dari diagonalnya membagi dua sama panjang

- Diagonal-diagonalnya saling tegak lurus

Gambarlah bangun tersebut, beri label dan sebutkan nama bangun!

Dari sifat-sifat bangun datar segiempat yang sudah kamu ketahui, apakah persegi merupakan persegi panjang? Jelaskan!

Perhatikan gambar berikut!

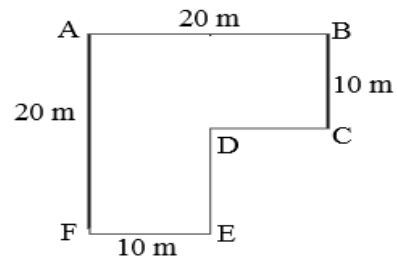

Seorang Petani memiliki sawah seperti gambar di atas. Petani tersebut akan membagi sawah dengan luas yang sama kepada 4 anaknya. Bagaimana membagi sawah menjadi 4 bagian yang sama? Tentukan berapa luas sawah yang didapatkan untuk setiap anak?

\section{HASIL}

Penelitian ini bertempat di Sekolah Dasar Islam Mohammad Hatta Kota Malang dengan jumlah sampel sebanyak 27 siswa kelas IV. Kepada seluruh sampel diberikan Van Hiele Geometry Test guna mengetahui level berpikir Van Hiele siswa. Dengan informasi ini, maka peneliti menentukan subjek penelitian sebanyak dua orang yang mencapai level 1 (analisis) Van 
Hiele untuk diberikan soal keterampilan geometri siswa. Setelah subjek mengerjakan soal, maka langkah selanjutnya yaitu wawancara yang dilakukan langsung oleh peneliti. Dari hasil analisis, peneliti mengambil dua orang subjek yang mencapai level 1 (analisis) Van Hiele. Subjek yang dipilih yaitu CAJ dan ADS. Berikut disajikan hasil tes keterampilan geometri siswa yang mencapai level 1 (analisis) menurut teori Van Hiele (Tabel 2).

Tabel 2. Hasil Tes Keterampilan Geometri Siswa Level 1

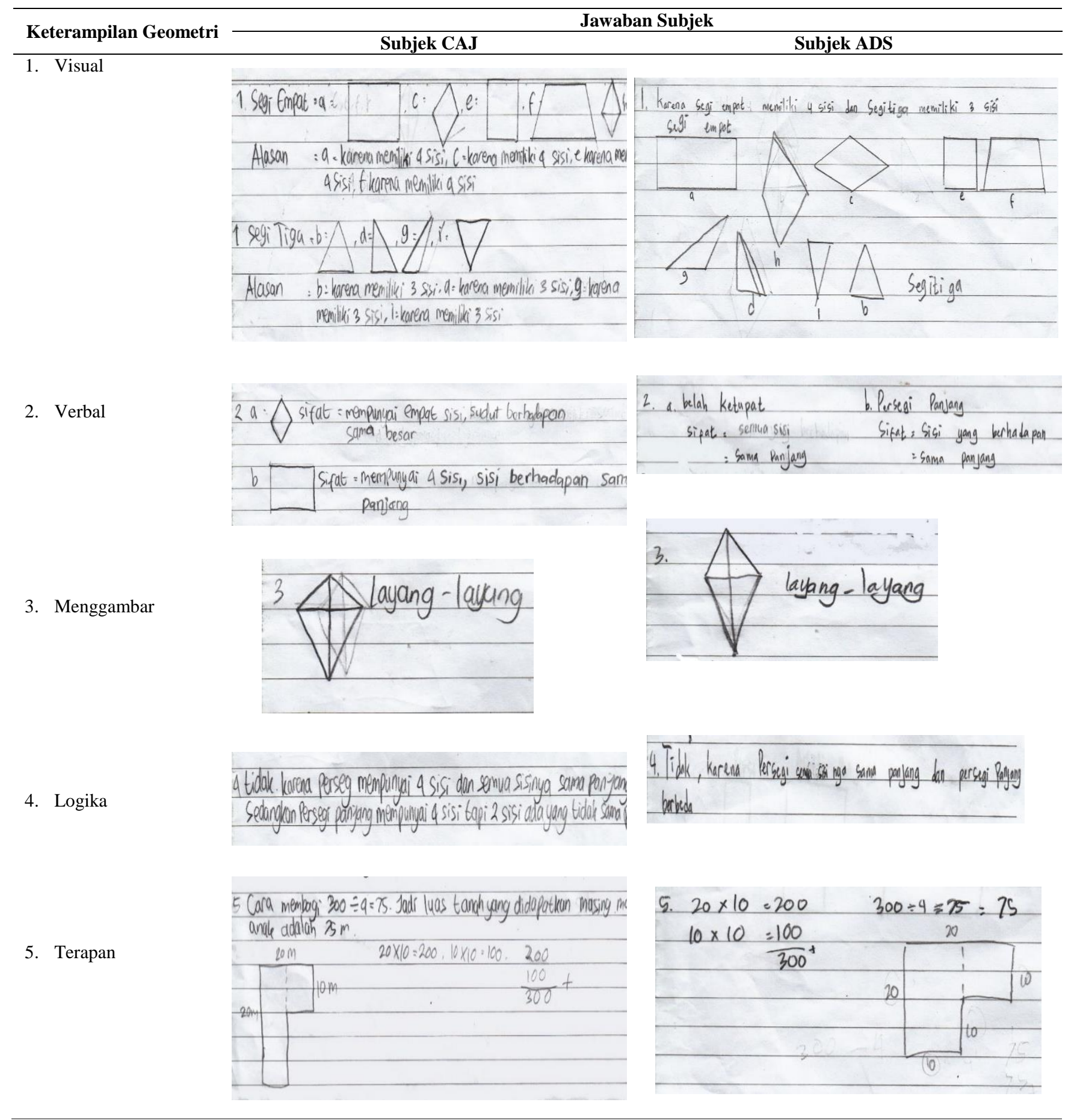

Berdasarkan Tabel 2 dapat dilihat bahwa subjek CAJ dan ADS mampu mengerjakan soal dengan baik pada keterampilan visual, verbal, menggambar, dan terapan. Subjek mampu mengelompokkan segiempat dan segitiga beserta alasan pengelompokkan, subjek mampu menyebutkan nama bangun datar dan sifat-sifatnya, subjek mampu menggambar bangun layang-lanyang berdasarkan sifat-sifat yang diketahui, dan subjek mampu menggunakan model geometri dalam menyelesaikan 
masalah dengan meskipun belum dapat diselesaikan dengan tuntas. Untuk keterampilan logika, subjek CAJ dan ADS masih belum dapat memahami maksud dari soal yang diberikan. Jawaban yang diberikan masih belum sesuai dengan indikator yang ada. Subjek tidak mampu menjelaskan keterkaitan antara sifat bangun persegi dan persegi panjang.

\section{PEMBAHASAN}

Berdasarkan data penelitian, kemampuan pemahaman geometri berdasakan level berpikir Van Hiele siswa masih jauh dari yang diharapkan karena dari hasil penelitian diperoleh siswa sebagian besar hanya mampu mencapai tingkat visualisasi dan analisis saja. Dari 27 siswa sebagai responden diperoleh data bahwa tingkat pemahaman geometri siswa sebagian besar hanya sampai pada level visualisasi yaitu level dimana siswa hanya mampu membedakan bentuk-bentuk geometri, mendefinisikan dan dapat menentukan unsur-unsurnya saja, pada level ini 17 orang siswa termasuk kedalamnya, yaitu sebanyak 63\% siswa. level analisis yaitu level dimana siswa mampu menganalisis komponen bangun-bangun, serta menemukan sifat/aturannya, pada level ini terdapat $18,5 \%$ siswa yang termasuk kedalamnya. Selain itu, sebanyak 18,5\% siswa tidak dapat mencapai level 0 . Hal ini seperti hasil yang ditemukan oleh Wu \& Ma (2006) yang mengatakan bahwa sebanyak 30\% dari siswa Taiwan yang merupakan responden penelitian belum mampu mencapai level terendah dari level berpikir geometri menurut teori Van Hiele. Wu \& Ma (2006) memberi nama kelompok siswa tersebut “Below Level 0”. Jadi, level berpikir geometri tertinggi siswa kelas IV SD Islam Mohamad Hatta adalah level 1 (analisis). Selanjutnya diberikan tes keterampilan geometri untuk mengetahui keterampilan geometri yang dimiliki siswa. Siswa yang ditetapkan sebagai subjek penelitian kemudian diwawancarai dengan tujuan untuk mengetahui keterampilan geometri siswa yang mencapai level 1 (analisis) Van Hiele. Analisis hasil tes dan wawancara diperoleh deskripsi keterampilan geometri untuk siswa yang berada pada level 1 (analisis) sebagaimana ditunjukkan pada tabel 3 .

Tabel 3. Keterampilan Geometri Siswa Level 1

\begin{tabular}{|c|c|c|}
\hline Keterampilan Geometri & Subjek CAJ & Subjek ADS \\
\hline 1. Keterampilan Visual & $\begin{array}{l}\text { Subjek CAJ dapat mengelompokkan bangun } \\
\text { segiempat dan segitiga serta dapat memberikan } \\
\text { alasan pengelompokkan dengan benar. }\end{array}$ & $\begin{array}{l}\text { Subjek ADS dapat mengelompokkan bangun } \\
\text { segiempat dan segitiga serta dapat memberikan } \\
\text { alasan pengelompokkan dengan benar. }\end{array}$ \\
\hline 2. Keterampilan Verbal & $\begin{array}{l}\text { Subjek CAJ mampu menyebutkan nama bangun } \\
\text { datar dengan benar, mampu menuliskan sifat-sifat } \\
\text { dari bangun datar tersebut, namun tidak lengkap. }\end{array}$ & $\begin{array}{l}\text { Subjek ADS mampu menyebutkan nama bangun } \\
\text { datar dengan benar, mampu menuliskan sifat-sifat } \\
\text { dari bangun datar tersebut, namun tidak lengkap. }\end{array}$ \\
\hline $\begin{array}{l}\text { 3. Keterampilan } \\
\text { Menggambar }\end{array}$ & $\begin{array}{l}\text { Subjek CAJ mampu menggambar bangun layang- } \\
\text { layang dengan benar sesuai dengan sifat-sifat yang } \\
\text { dimiliki bangun tersebut, mampu menentukan } \\
\text { nama bangun tersebut, namun tidak melabeli titik } \\
\text { sudutnya. }\end{array}$ & $\begin{array}{l}\text { Subjek ADS mampu menggambar bangun layang- } \\
\text { layang dengan benar sesuai dengan sifat-sifat } \\
\text { yang dimiliki bangun tersebut, mampu } \\
\text { menentukan nama bangun tersebut, namun tidak } \\
\text { melabeli titik sudutnya. }\end{array}$ \\
\hline 4. Keterampilan Logika & $\begin{array}{l}\text { Subjek CAJ tidak mampu menjelaskan keterkaitan } \\
\text { antara sifat bangun persegi dan persegipanjang. }\end{array}$ & $\begin{array}{l}\text { Subjek ADS tidak mampu menjelaskan } \\
\text { keterkaitan antara sifat bangun persegi dan } \\
\text { persegi panjang. }\end{array}$ \\
\hline $\begin{array}{l}\text { 5. Keterampilan } \\
\text { Terapan }\end{array}$ & $\begin{array}{l}\text { Subjek CAJ sudah dapat menggunakan model } \\
\text { geometri untuk menyelesaikan masalah dengan } \\
\text { benar meskipun belum dapat diselesaikan dengan } \\
\text { tuntas. }\end{array}$ & $\begin{array}{l}\text { Subjek ADS sudah dapat menggunakan model } \\
\text { geometri untuk menyelesaikan masalah dengan } \\
\text { benar meskipun belum dapat diselesaikan dengan } \\
\text { tuntas. }\end{array}$ \\
\hline
\end{tabular}

Berdasarkan tabel 3 dapat dilihat bahwa siswa pada level 1 (analisis) mampu menyelesaikan soal pada keterampilan visual. Siswa dapat mengelompokkan bangun segiempat dan segitiga serta dapat memberikan alasan pengelompokkan dengan benar. Pada keterampilan verbal, siswa dapat menentukan nama bangun datar dan mampu menuliskan sifat-sifat dari bangun belah ketupat dan persegi panjang, tetapi tidak lengkap. Hal ini sesuai dengan yang dikemukakan oleh Watan \& Sugiman (2018) bahwa siswa yang mencapai level 1 (analisis) dapat menentukan sifat-sifat gambar melalui pengamatan, pengukuran, menggambar, dan pemodelan. Level ini sering disebut juga level deskriptif. Pada level ini, siswa dapat menyebutkan sifat-sifat yang dimiliki suatu bangun. Sebagai contoh adalah suatu persegi panjang memilki empat sudut siku-siku. Jadi, pada level ini, siswa sudah mengenal bangun-bangun geometri berdasarkan ciri-ciri dari masing-masing bangun. Dengan kata lain, pada level ini siswa sudah dapat menganalisis bagian-bagian yang ada pada suatu bangun dan mengamati sifat-sifat yang dimiliki oleh bangun tersebut. Contoh lain pada level ini adalah siswa mengatakan bahwa suatu bangun merupakan persegi karena bangun itu memiliki empat sisi sama panjang (Prabowo \& Ristiani, 2011). 
Pada keterampilan menggambar, siswa mampu menggambar bangun datar dengan benar berdasarkan sifat-sifat yang diberikan, mampu menentukan nama bangun tersebut, namun tidak melabeli titik sudutnya. Hal ini sejalan dengan penelitian Astuti dkk (2018) yang mengatakan bahwa siswa yang mencapai level 1 (analisis) sudah mampu membuat gambar bangun datar berdasarkan informasi verbal yang diberikan. Hal ini dikarenakan untuk menggambar bangun berdasarkan sifat-sifat bangun, maka siswa harus memahami sifat-sifat dari bangun tersebut. Siswa yang mencapai level 1 sudah memahami sifat-sifat yang dimiliki oleh suatu bangun sehingga siswa mudah membuat bangun berdasarkan sifat-sifat bangun yang diketahui.

Pada keterampilan logika, siswa tidak dapat mengungkapkan keterkaitan antara sifat bangun persegi dan persegipanjang. Hal ini sesuai dengan yang dikemukakan oleh Crowley (2017) bahwa siswa yang mencapai level 1 (analisis) belum mampu menjelaskan hubungan antara sifat-sifat suatu bangun. Hal ini dikarenakan siswa yang mencapai level 1 mengenal sifat-sifat bangun geometri yang didasarkan pada analisis informal tentang bagian-bagian bangun dan atribut-atribut komponennya. Siswa melihat bahwa suatu bangun mempunyai bagian-bagian tertentu yang dapat dikenali. Namun demikian, siswa belum sepenuhnya dapat menjelaskan hubungan antara sifat yang satu dengan sifat yang lain, siswa sama sekali belum dapat melihat hubungan antara beberapa bangun, dan definisi abstrak belum atau tidak dapat dimengerti. Suatu contoh, anak belum dapat menyatakan bahwa persegipanjang merupakan jajargenjang.

Pada keterampilan terapan, siswa sudah dapat menggunakan model geometri untuk menyelesaikan masalah dengan benar meskipun belum dapat diselesaikan dengan tuntas. Hal ini sesuai dengan penelitian Sunardi \& Yudianto (2015) yang mengatakan bahwa siswa yang mencapai level 1 (analisis) sudah mampu memahami masalah yang ada pada soal. Siswa memahami langkah apa yang harus dilakukan untuk memecahkan masalah geometri tersebut, namun masih belum tepat dalam menyelesaikan soal geometri. Hal ini dikarenakan, siswa yang mencapai level 1 mengalami kesulitan dalam mengungkapkan ide-ide yang ia miliki untuk menyelesaikan soal yang diberikan, siswa melakukan kesalahan dalam proses pengukuran dan menentukan suatu konsep, dan tidak mampu membuat kesimpulan dari proses pengukuran dan penyelesaian soal.

\section{SIMPULAN}

Berdasarkan hasil penelitian dan pembahasan, maka dapat disimpulkan bahwa keterampilan geometri siswa untuk level 1 (analisis) Van Hiele yaitu sebagai berikut: Untuk keterampilan visual, siswa mampu mengelompokkan bangun segiempat dan segitiga dengan benar dan memberikan alasan pengelompokkan dengan benar. Untuk keterampilan verbal, siswa mampu menyebutkan nama bangun datar dengan benar dan mampu menuliskan sifat-sifat dari bangun datar tersebut, namun tidak lengkap. Untuk keterampilan menggambar, siswa mampu menggambar bangun datar dengan benar berdasarkan sifat-sifat yang diberikan, mampu menentukan nama bangun tersebut, namun tidak melabeli titik sudutnya. Untuk keterampilan logika, siswa tidak mampu mengungkapkan keterkaitan antara sifat bangun persegi dan persegi panjang. Untuk keterampilan terapan, siswa menggunakan model geometri untuk menyelesaikan masalah dengan benar meskipun belum dapat diselesaikan dengan tuntas. Hasil penelitian ini diharapkan dapat dijadikan sebagai sumber informasi bagi peneliti lain yang akan meneliti lebih lanjut tentang keterampilan geometri siswa untuk level berpikir yang lebih tinggi berdasarkan teori Van Hiele.

\section{DAFTAR RUJUKAN}

Astuti, R., Suryadi, D., \& Turmudi. (2018). Analysis on Geometry Skills of Junior High School Students on the Concept Congruence Based on Van Hiele's Geometric Thinking Level. Journal of Physics: Conference Series, 1132, 12036. https://doi.org/10.1088/1742-6596/1132/1/012036

Burger, W. F., \& Shaughnessy, J. M. (2016). Characterizing the van Hiele Levels of Development in Geometry. Journal for Research in Mathematics Education, 17(1), 31-48.

Crowley, M. (2017). The van Hiele Model of the Development of Geometric Thought. Yearbook of National Council of Teachers of Mathematics, 1-16. Retrieved from http://www.csmate.colostate.edu/docs/math/mathactivities/june2007/The van Hiele Model of the Development of Geometric Thought.pdf

Heruman. (2007). Model Pembelajaran Matematika di Sekolah Dasar. Bandung: Remaja Rosdakarya.

Hofer, A. (2008). Geometry Is More Than Proof. American Association for the Advancement of Science, 17(4), 145-148. https://doi.org/10.1177/0306312708091929

Kim, Y. R. (2016). Analysis of Teaching of Van Hiele Geometry in Schools In Korea. Proceedings of 4thInternational Congress of Educational Sciences and Development, 9(June), 21-25.

Musser, G.L., Burger, W.F., \& Peterson, B. E. 2011. Mathematics for Elementary Teachers, a Contemporary Approach (9th ed.). America: John Wiley \& Sons, Inc.

NCTM. (2000). Principles and Standars for School Mathematics. United States of America: The National Council of Teachers of Mathematics, Inc.

Ningrum, R. W., Yulianti, M., Helingo, D. D. Z., \& Budiarto, M. T. (2018). Students' Misconceptions on Properties of Rectangles. Journal of Physics: Conference Series, 947(1). https://doi.org/10.1088/1742-6596/947/1/012018

Ozkan, M., \& Bal, A. P. (2017). Analysis of the Misconceptions of 7th Grade Students on Polygons and Specific Quadrilaterals. Eurasian Journal of Educational Research, 17(67), 161-182. https://doi.org/10.14689/ejer.2017.67.10

Prabowo, A. \& Ristiani, E. (2011). Rancang Bangun Instrumen Tes Kemampuan Keruangan Pengembangan Tes Kemampuan Keruangan Hubert Maeier dan Identifikasi Penskoran Berdasar Teori Van Hiele. Jurnal Kreano, 2(2), $72-87$. 
Rafianti, I. (2016). Identifikasi Tahap Berpikir Geometri Calon Guru Sekolah Dasar Ditinjau dari Tahap Berpikir Van Hiele. JPPM (Jurnal Penelitian dan Pembelajaran Matematika), 9(2), 159-164.

Rahimah, N., \& Asy’ari. (2017). Keterampilan Dasar Geometri Siswa Kelas V Dalam Menyelesaikan Soal Bangun Datar Berdasarkan Kemampuan Matematika di MI AL Istiqomah Banjarmasin. Math Didactic: Jurnal Pendidikan Matematika, 3(1), 55-63.

Škrbec, M., \& Čadež, T. H. (2015). Identifying and Fostering Higher Levels of Geometric Thinking. EURASIA Journal of Mathematics, Science and Technology Education, 11(3), 601-617. https://doi.org/10.12973/eurasia.2015.1339a

Sugiyono. (2015). Metode Penelitian Kuantitatif, Kualitatif, dan R \& D. Bandung: Alfabeta.

Sunardi., \& Yudianto, E. (2000). Antisipasi Siswa Level Analisis Dalam Menyelesaikan Masalah Geometri. AdMathEdu: Mathematics Education, Mathematics, and Applied Mathematics Journal, 5(2), 203-215.

Usiskin, Z. (1982). Van Hiele Levels and Achievement in Secondary School Geometry: Final report of the Cognitive Development and Achievement in Secondary School Geometry (CDASSG) Project. US: Department of Education, University of Chicago.

Vojkuvkova, I. (2012). The van Hiele Model of Geometric Thinking. WDS'12 Proceedings of Contributed Papers, 1, $72-75$.

Watan, S., \& Sugiman. (2018). Exploring the Relationship Between Teachers' Instructional and Students' Geometrical Thinking Levels based on Van Hiele Theory. Journal of Physics: Conference Series, 1097(1). https://doi.org/10.1088/1742-6596/1097/1/012122

Wu, D. B. \& Ma, H. L. (2006). The Distributions of Van Hiele Levels of Geometric Thinking Among $1^{\text {st }}$ Through $6^{\text {th }}$ Graders. Proceedings $30^{\text {th }}$ Conference of the International Group for the Psychology of Mathematics Education, 5, 409-416.

Wu, D. B. \& Ma, H. L. (2010). Development of Wu-Ma Test of the Van Hiele Levels of Geometrical Thinking Based on Grey Relational Analysis. New Aspects of Signal Processing, Computational Geometry and Artificial Vision, (August 2010), 110-114. 